\title{
The Economic and Environmental Impacts of Constructing Hydro Power Plants in Turkey: A Dynamic CGE Analysis (2004-2020)
}

\section{Levent Aydın*}

Ministry of Energy and Natural Resources, Moussa Bouh Odowa, Turkey.

Email: leventaydin60@gmail.com

Received October $31^{\text {st }}, 2010$; revised November $24^{\text {th }}, 2010$; accepted November $25^{\text {th }}, 2010$.

\begin{abstract}
Since Turkey's economy and population is rapidly growing, Turkey mostly meets its energy demand from imported fossil sources due to the very limited indigenous oil and natural gas resources. However, Turkey has abundant renewable resources especially, hydro power potential to be used for generation of electricity. But only one-third of this significant economical potential could be used. This usage seems insufficient when compared with that of European countries. In order to analyze the potential long term impacts of the hydro power expanding shock on some macroeconomic variables of interest such as GDP, real consumption, real investment, exports, imports, trade balance, and carbon emissions, we developed TurGEM-D, a dynamic multisectoral general equilibrium model of the Turkish economy. Using TurGEM-D, we analyzed the impact of hydro power shock under policy scenario doubling hydro power generation. The simulation results show that doubling hydro power have slightly positive effects on macro indicators and carbon emissions for Turkish economy.
\end{abstract}

Keywords: Hydro Power Generation, Dynamic CGE, Turkey, Carbon Emission

\section{Introduction}

Turkey is seeking to cover an imminent shortfall in electricity as well as cut its dependence on foreign energy resources, mainly natural gas. One of the Turkish energy policies is to designate hydro and nuclear power as an essential source of energy, meeting at least one-fifth of Turkey's power needs within the next decades.

On the other hand, Turkey is not a rich country in terms of the hydrocarbon (oil and natural gas, etc.) potential to be used for generation of electricity. Therefore Turkey has a strategy for developing the hydropower potential and expects a few hundred small hydro power plants to be constructed in the long run. Moreover Turkey must discover new and renewable energy resources. However, new and renewable resources other than hydro will not be sufficient to produce large amounts of electricity in the coming decades even if major efforts were made to develop them.

Eventually, Turkey must base its power generation strategy on constructing nuclear and hydro power plants for coming decades in order to minimize foreign dependency of natural gas and carbon dioxide $\left(\mathrm{CO}_{2}\right)$ emis- sions.

The other main characteristic of strategy for power generation is the fact that the strategy is highly supplyoriented. Emphasis has been placed on ensuring additional power supply to meet the growing demand while energy efficiency has been lower priority. In spite of new regulations and more activities have recently been launched to enhance energy efficiency, there is obviously a long way to go. As such, studies conducted by the Turkish government officials have demonstrated that Turkey has $25-30 \%$ energy conservation potential.

The aim of this paper is to evaluate the economic and environmental impacts of constructing new hydro power plants as alternative fossil-fired power plants. In order to analyze this policy option we specifically developed TURGEM-D (Turkey General Equilibrium Model-Dynamic) which is dynamic, multisectoral and applied general equilibrium model of the Turkish economy. The model structure of TURGEM-D mainly was based on ORANI-INT model except production structure. The production structure is divided into two types: fossil fired power generation and hydro power generation. 
TURGEM-D database was compiled from the I/O tables of Turkish economy with reference year of 2004 . Both sectors and commodities of this data base were firstly aggregated into 8 sectors and commodities as follows: agriculture, coal, oil, gas, oil products, energy intensive industries, electricity, other industries and services. The electricity sectors further disaggregated $2 \mathrm{sec}-$ tors and its commodities with additional data of Turkish power sector.

We expect hydro power generation of Turkish economy is to be about twofold by increasing average annual production from 62 billion $\mathrm{kWh}$ to 118 billion $\mathrm{kWh}$ in the next decade (2010-2020). The policy scenarios are to diversify fuel sources as well as supply routines and origin and they also aims to reduce import dependence of natural gas and coal in power generation while increaseing the share of renewable hydro and nuclear power in Turkey. In the long term options we expect that hydro power make significant contribution to power generation. We can use real GDP and $\mathrm{CO}_{2}$ emission as a macroeconomic variable to evaluate impacts of hydro power plants on Turkish economy.

\section{Hydro Power Potential and Policy in Turkey}

Turkey has theoretical hydropower potential of 433 billion $\mathrm{kWh}^{1}$, technically feasible potential of 216 billion $\mathrm{kWh}$, and technically economical potential of 140 billion $\mathrm{kWh}$. In 2009, there were 213 hydroelectric power plants in operation in Turkey. Total hydropower plants capacity was 14,300 MW with average annual total production of $50,000 \mathrm{GWh}$ which corresponds to $36 \%$ of the total economical potential. In addition 145 hydro plants with total capacity of 7,286 MW are under construction, corresponding to about $23,770 \mathrm{GWh}$ of additional annual power generation. The remaining potential of $66,230 \mathrm{GWh}$ of total 140 billion $\mathrm{kWh}$ will use to construct the 200 hydropower plants in the coming decades. This would bring the number of hydropower plants to 558 and the total installed capacity to $44,200 \mathrm{MW}[1,2]$.

Although Turkey has a big potential for hydro power, the utilization of this potential is a question of determining and implementing sound, long-term energy planning and politics that should prepare the best and reliable environment for the national and international investors $[3,4]$. Place and being a source of re- newable energy in power, the lack of negative influence of the environment, low operating and maintenance costs make it necessary to develop as possible. Giving priority to the use of water resources in Turkey has been adopted as a national policy. Installed hydroelectric power, even though significant progress achieved to date, is not enough. Hydroelectric energy has to be addressed with the development of a new strategy.

Table 1 indicates that total the installed capacity will increase to $48,817 \mathrm{MW}$ in 2010 and to $96,349 \mathrm{MW}$ in 2020. The installed hydropower capacity is anticipated to increase to $18,234 \mathrm{MW}$ in 2010 and to $34,076 \mathrm{MW}$ in 2020 . Thus, an additional $1,584 \mathrm{MW}$ of hydro capacity should be added to the system annually over the next 10 years [5].

The production of hydroelectric power plants, is dependent on rainfall conditions change in the share of total production each year, however, the 20 -and $30 \%$ of electric energy in Turkey is produced from water. As shown Table 1 the renewable power generation with rainfall conditions will increase to 62 Billion $\mathrm{kWh}$ in 2010 to 118 Billion $\mathrm{kWh}$ in 2020.

In the recent years, more emphasis has been put on the environmental integration of small hydro plants into river systems in order to minimize environmental impacts, incorporating new technology and operating methods in Turkey.

Table 1. Turkey's long-term electricity supply projections.

\begin{tabular}{|c|c|c|c|c|c|c|}
\hline \multirow{3}{*}{ Power Plant Type } & \multicolumn{3}{|c|}{2010} & \multicolumn{3}{|c|}{2020} \\
\hline & \multirow{2}{*}{ Installed capacity (MW) } & Rain & Rainless & \multirow{2}{*}{ Installed capacity (MW) } & Rain & Rainless \\
\hline & & \multicolumn{2}{|c|}{ Billion kWh } & & \multicolumn{2}{|c|}{ Billion kWh } \\
\hline Fuel based & 30,583 & 211 & 211 & 62,273 & 425 & 426 \\
\hline Renewable based & 18,234 & 62 & 46 & 34,076 & 118 & 77 \\
\hline Total supply & 48,817 & 273 & 257 & 96,349 & 543 & 503 \\
\hline
\end{tabular}

Sources: TEIAS, Turkey Electricity Generation Planning Study (2005-2020/October 2004)

${ }^{1}$ It is almost $1 \%$ of world total potential and $16 \%$ of the total hydropower capacity in Europe (Balat, 2007). 
By the end of 2008 Turkey was producing $17 \%$ of its electricity from renewable energy sources. The revised strategy paper for the electricity sector set a target of producing $25 \%$ of the country's electricity from renewable sources by the end of 2020. Considering that electricity consumption is expected to double by the same date, this objective will require significant efforts. Turkey's energy policy has been revised in line with EU policy in the context of enlargement process.

In addition to the publication of Electricity Market Law (Law No. 4628) led to the establishment of Electricity Market Regulatory Authority and the publication of Renewable Energy Law (LawNo.5346) guarantees to buy electricity from legal entities with a price of $€ 5.5 \mathrm{cent} /$ $\mathrm{kWh}$ by government for duration of 10 years, the Law No. 5784, was published stating that the legal entities are not required to apply for a license to generate electricity from renewable energy up to a capacity of $500 \mathrm{~kW}$ and government guarantees the buy the excess electricity. These laws on renewable energy utilization for electricity generation in Turkey have brought some improvements to the market. However, they must be revised or redesigned to fulfill the requirements of EU policy as Turkey is an EU- candidate country [6].

\section{Modelling Framework and Simulation Design}

Before proceeding with the model simulation, we must first briefly discuss the TurGEM-D model and its database, originally developed by Malakellis [7]. We take the standard ORANI-INT model and introduce some changes to make it consistent with power generation. We first show that the structure of TurGEM-D model allows for analysis of increasing supply of renewable power generation. The most significant features that distinguish TurGEM from ORANI-INT are the inclusion of interfuel substitution, power generation, capital energy substitution/complementarity, and dynamic mechanism capable of projecting the development of the economy through time. With TurGEM-D we have produced annual projections of the Turkeys $\mathrm{CO}_{2}$ emission, GDP growth rate, and other economic variables.

\subsection{Model Structure and Data}

TurGEM-D is dynamic computable general equilibrium model of Turkish economy. The dynamic Turkish model described below was developed from the Australian model originally presented in ORANI [8] and has its core the dynamic CGE model described in ORANI-INT model. Model structure is modified from ORANI-INT model to make suitable for analyzing energy, natural resources and climate change issues.
The model database was compiled from the 2004 Turkish Input-Output table [9] and Energy Statics [10]. The 64 sectors in Turkish economy are first aggregated to 8 sectors, which are thought to be critical for this analysis. Electricity sector further disaggregated into fossil fired electricity generation (oil-fired, coal-fired, gas-fired) and hydro power generations. The electricity industry is able substitute alternative power generation technologies in response to changes in relative costs. The output of the power sector is an aggregate of the power generated from each of these technologies. The production structure of the power generation sectors in TurGEM-D model is illustrated by the nested structure and all electricity generated from these technologies as shown in Figure 1. In addition, power generated from renewable energy sources is designed as a separate sector so as to analyze Turkish energy policies in line with the EU policy.

The production structure of non-electricity sectors in TurGEM-D model is represented by the nested structure of energy composite (coal, oil products, gas) and primary factor composite (land, labor, capital).

The dynamic structure of TurGEM-D is illustrated in Figure 2. The model is replicated " $T$ " times by indexing all variables in the model with respect to time, where "T" is the length of time horizon (in years). Sectoral investments and aggregate household expenditures are exogenous in the model. The model equations are dynamic: they express relationships among variables at different points in time.

As shown in Figure 1, on the production side of the model, energy is taken out of the intermediate input 'nest' to be incorporated into the 'value-added' nest. Incorporation of energy into the value-added nest is handled in two steps. First, following Burniaux and Truong (2002), energy commodities are first divided into 'electricity' and 'non-electricity.' Certain degree of substitution is allowed among the non-electricity inputs $\left(\sigma_{\mathrm{NELY}}\right)$ as well as between the electricity and the non-electricity inputs $\left(\sigma_{\mathrm{ENER}}\right)$. The energy composite is then combined with capital to produce an energy-capital composite. This is in turn combined with other primary factors in a value-added-energy (VAE) nest through a CES structure. The substitution elasticity between capital and energy composite $\left(\sigma_{\mathrm{KE}}\right)$ is still assumed to be positive (indicating energy and capital are substitutes in the 'inner nest'). However, provided the value of $\sigma_{\mathrm{KE}}$ is set at a level lower than $\sigma_{\mathrm{VAE}}$, the overall substitution elasticity (as viewed from the 'outer nest') between capital and energy may still be negative [11]. More precisely, we make use of the formula derived by Keller [12] which specifies the relationship between the 'inner' and 'outer' elasticity of substitution between $\mathrm{K}$ and $\mathrm{E}$ as follows: 


$$
\sigma_{\mathrm{KE}-\text { outer }}=\left(\sigma_{\mathrm{KE}-\text { inner }}-\sigma_{\mathrm{VAE}}\right) / \mathrm{S}_{\mathrm{KE}}+\sigma_{\mathrm{VAE}} / \mathrm{S}_{\mathrm{VAE}}
$$

where $\mathrm{S}_{\mathrm{KE}}$ is the cost share of the KE-composite in the outer (value-added) nest, and $\sigma_{\mathrm{KE}-\text { inner }}$ and $\sigma_{\mathrm{KE}-\text { outer }}$ indicate the inner and outer substitution elasticities between $\mathrm{K}$ and E, respectively.

In TurGEM-D, the (inner) value of $\sigma_{\mathrm{KE}}$ is assumed to be 0.5 for most industries (including electricity), and is set equal to 0.0 for coal, oil, gas, petroleum and coal products, and agriculture. We followed Burniaux and Truong [13] in adopting the parameter values. The value of $\sigma_{\mathrm{VAE}}$ ranges from 0.2 to 1.45 and this seems to be slightly larger than the values adopted by other models. ${ }^{2}$

As indicated by the directions of arrow in Figure 2 some variables are linked through time via forward and backward linkages. For investment $\left(\mathrm{I}_{\mathrm{t}}\right)$, the backward linkages are provided by the capital accumulation equations $\left(\mathrm{K}_{\mathrm{t}}\right)$ while the forward linkages are provided by the specification of forward looking rates of return. Similarly consumption $\left(\mathrm{C}_{\mathrm{t}}\right)$ in each period is linked (forward) to future prices and income while current debt $\left(D_{t}\right)$ is linked (backwards) to past savings. Only one representative household is modeled in the model and capital is assumed to be sector-specific. This means that the model incorporates 9 independent types of forward-looking behavior where 8 relate to the planning of sectoral investments while the other relates to the planning of aggregate consumption. There are also 9 accumulation

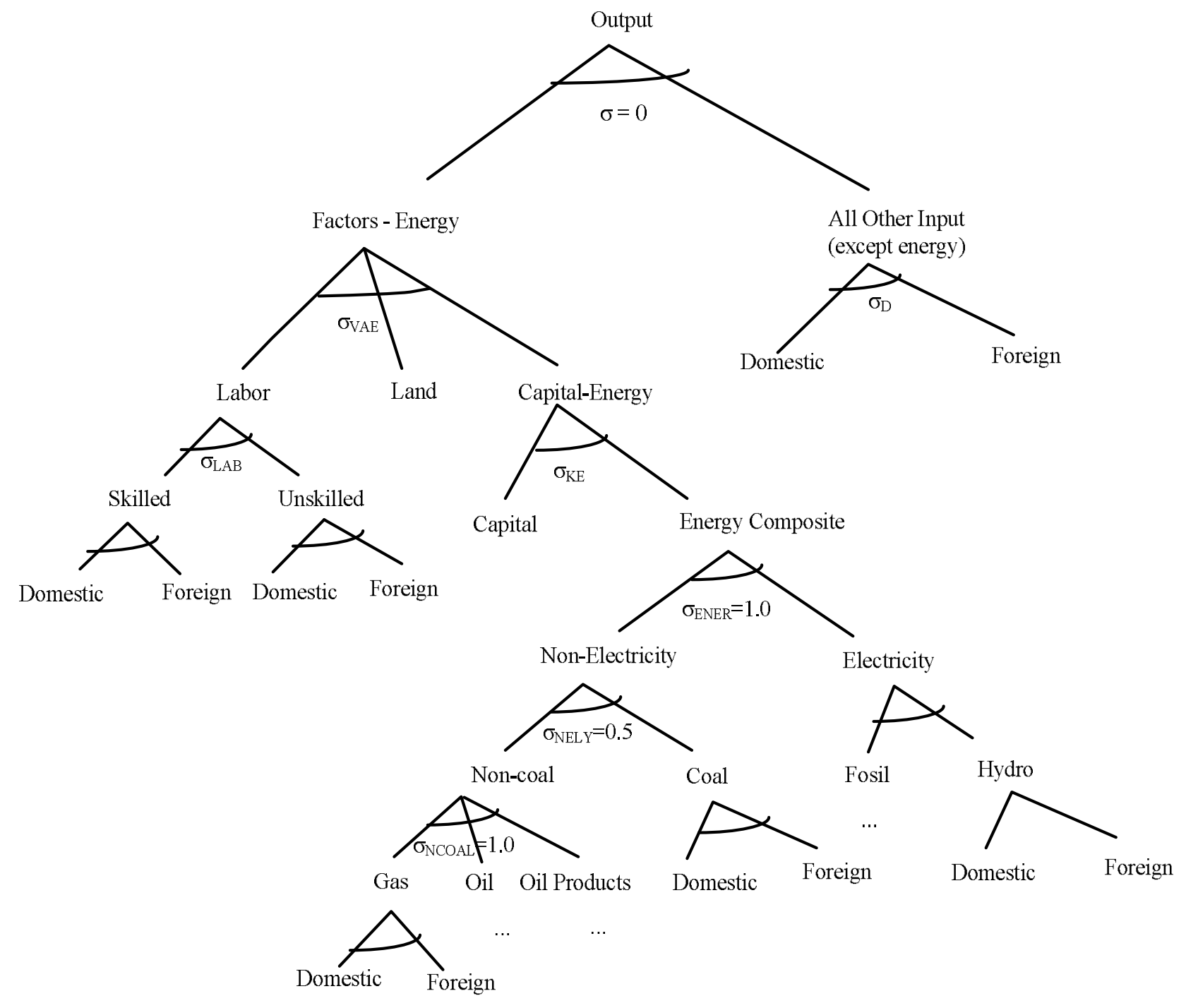

Figure 1. Production structure of the model.

${ }^{2}$ See Tables 9 and 10 in Burniaux and Truong (2002: 32) for more details on the values of $\sigma_{\mathrm{KE}}$ and $\sigma_{\mathrm{VAE}}$ used by other models. 
identities modeled: again 8 of these relate to the accumulation of sectoral capital stocks and the final one relates to the accumulation of foreign debt [7].

Investors can allocate their funds across 9 types of perfectly substitutable assets. These include shares in the 8 industries and foreign and domestic bonds. Zero pure profits are assumed in all activities with commodity and carbon taxes on commodity flows putting wages between basic prices and purchasers prices.

The demand and supply of commodities is determined by the optimizing behavior of producers, investors and consumers in the context of competitive markets. Government demands for commodity are assumed to be fixed or exogenous while foreign demand is specified in an ad hoc manner. The demand for factors and supply of capital are also derived from optimizing behavior and competitive market assumptions. The supply of labor and agricultural land can be specified exogenously or they can be determined by demand [7].
We account for carbon dioxide emissions arising from the combustion of fossil fuels such as coal, natural gas, and petroleum products. We assume that carbon dioxide emissions are closely related to energy consumption. We assign user, fuel, and source specific emissions coefficients $\left(\mathrm{CO}_{2}\right.$ per dollar, at 2004 value) and prorate the fuel specific 2004 national $\mathrm{CO}_{2}$ inventories among users. This produces the $\mathrm{CO}_{2}$ emissions matrix by fuel commodities, commodity sources and users. Table 2 shows $\mathrm{CO}_{2}$ emissions from 3 fuels (domestic plus imported): coal, natural gas, oil.

\subsection{Simulation Design}

For policy simulation, model is solved over 16-year time horizon and results are reported as percent deviations from the baseline scenario. In setting up the simulation, we need to specify the closure for the model and the set of relevant shocks for the exogenous variables.

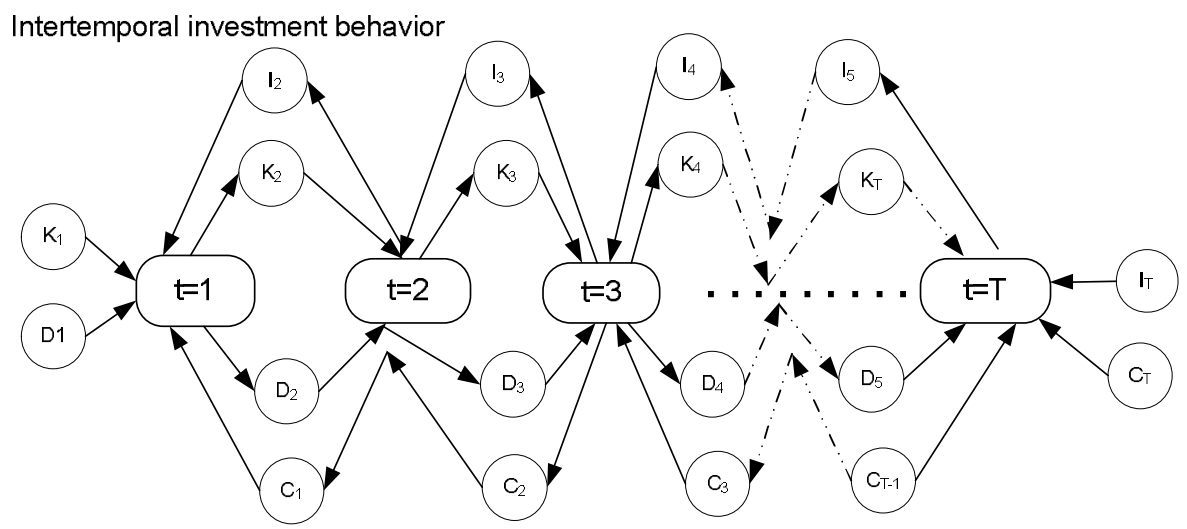

Intertemporal consumption behavior

Figure 2. Dynamic mechanism of the model.

Table 2. Turkey's $\mathrm{CO}_{2}$ emissions by user (2004, million tons).

\begin{tabular}{lcccccc}
\hline & \multicolumn{3}{c}{ Domestic } & \multicolumn{3}{c}{ Imported } \\
\cline { 2 - 7 } & Coal & Gas & Oil Products & Coal & Gas & Oil Products. \\
\hline Agriculture & 0 & 0 & 10 & 0 & 0 & 3 \\
Energy intensive industries & 0 & 0 & 4 & 1 & 1 & 1 \\
Coal fired power plants & 48 & 0 & 0 & 11 & 0 & 0 \\
Oil fired power plants & 0 & 0 & 10 & 0 & 0 & 3 \\
Gas fired power plants & 0 & 0 & 0 & 0 & 29 & 0 \\
Other industry services & 14 & 0 & 42 & 8 & 5 & 11 \\
Households & 4 & 3 & 20 & 5 & 4 & 5 \\
Total & 65 & 3 & 86 & 26 & 39 & 23 \\
\hline
\end{tabular}

Source: GTAP 6 database 
In the "balanced growth" baseline scenario used as the control scenario, the economy converges to a balanced 5 percent $^{3}$ average annual growth asymptotically, all real variables grow at 5 percent per annum and all prices are stationary.

The past behavior of agents is taken as given in the model. This implies that any variable defined for year 0 is exogenous. Because we have specified a 1-year gestations lag in the capital creation process. The amount of capital that sectors have at disposal in year 1 is characterized by a short-run equilibrium in which the supply of sectoral capital stock cannot be altered. Beyond year one, however, the supply of sectoral capital stocks is allowed to change so as to equalize the rate of return on capital. Arbitrage conditions that relate risk adjusted sectoral rates of return to the interest rate are enforced by making the capital stock shifter variable exogenous [7].

For many variables TurGEM-D has no formal theory and, typically, the values of these variables are specified exogenously. These variables are technical change and consumer tastes, indirect and carbon tax tools, risk factors, foreign prices, foreign interest rates, transfer overseas, population, and aggregate real government expenditures. TurGEM-D model is implemented and solved by GEMPACK $^{4}$ software [14-16]

To analyze the results of simulation it is convenient to divide the 16 years time horizon of the experiment into three sub-intervals. The period of 2004-2009 is the preshock years. The second sub-interval analyzed includes year of 2010, the year in which the hydro power plant shock is initially implemented. The supply of hydro power plant was annually increased by $7 \%$. Next, the transition from year to the long run represented by the period of 2011-2020 is discussed.

The initial database of model is the 2004 input-output tables. Two situations are specified as follows.

1) Historical or pre-shock closure in the period of 2004-2009: Since official data on private consumption, investment, government consumption, exports, exchange rate and labor employed are available from the Turkish Statistics [9], we set growth rates of these variables as exogenous.

2) Forecast closure in the period 2010-2020: Most exogenous variables in the historical closure for the period 2004-2009 are set endogenous in the forecast closure. In the baseline forecast, private consumption, investment

${ }^{3}$ OECD statics indicate a $5 \%$ average annual GDP growth for the last decade. (OECD country statistical profile, 2010) downloadable at http://stats.oecd.org/index.aspx? queryid $=2357 \#$.

${ }^{4}$ GEMPACK is developed by the Centre of Policy Studies, Monash University, Australia.

${ }^{5}$ Exchange rates are assumed to be fixed in the model. Even though Turkey has switched to flexible exchange rate system since 2001, there have not been big fluctuations in recent years. http://www.tcmb.gov.tr. expenditure, government consumption, exports and imports are determined in the model.

\section{Simulation Results}

This section discusses the simulation results. We first discuss the impact of power generation shock to certain macroeconomic indicators and sectoral output as well, followed by a discussion on the impact of the shock on carbon emissions.

\subsection{Impact of Expanding Hydro Power Generation on Macro Indicators}

The simulation results are presented in a series of real GDP growth and real consumption, real investment, exports, imports, and sectoral outputs as the deviation from baseline scenario as depicted in Figure 3.

The scenario looks into the economic and environmental effects of increasing supply of hydro power generation on Turkish economy. The supply of hydro power generation target for 2020 is doubling the supply of 2010 . In order to achieve this energy policy target, Turkey needs to provide an incentive. Production and investment subsidy in this sector is used as the needed incentives in this simulation. Therefore, Figure 3 shows that real GDP, real consumption, real investment annually increase by $0.14,0.13$, and 0.07 percent respectively in the period of 2010-2020. While exports increase by 0.31 percent, imports also increase by 0.19 percent in the same period.

The terms of trade and allocative efficiency induced by expanding hydro power generation allow expanding GDP by 0.144 percent per annum under fixed exchange rates $^{5}$. Given that the trade account must be balanced in year 16, the deterioration in terms of trade means that any increase in the volume of imports must be more than offset by an increase in export volumes. In year of 2020 the share of exports and imports are 0.34. As shown Figure 3, in year of 2020 since both export volumes increase by 0.31 percent and import volumes increase by 0.19 percent, terms of trade deteriorates. To see show how the increase in real GDP is divided among foreigners and among the various domestic agents we use the definition of percentage change in real GDP from the expenditure side (gdp),

$$
\operatorname{gdp}_{t}=\frac{\mathrm{C}_{\mathrm{t}}}{\mathrm{GDP}_{\mathrm{t}}} \mathrm{c}_{\mathrm{t}}+\frac{\mathrm{I}_{\mathrm{t}}}{\mathrm{GDP}_{\mathrm{t}}} \mathrm{i}_{\mathrm{t}}+\frac{\mathrm{G}_{\mathrm{t}}}{\mathrm{GDP}_{\mathrm{t}}} \mathrm{g}_{\mathrm{t}}+\frac{\mathrm{E}_{\mathrm{t}}}{\mathrm{GDP}_{\mathrm{t}}} \mathrm{e}_{\mathrm{t}}+\frac{\mathrm{M}_{\mathrm{t}}}{\mathrm{GDP}_{\mathrm{t}}} \mathrm{m}_{\mathrm{t}}
$$$$
\mathrm{t}=1, \mathrm{~L}, \mathrm{~T}
$$

where the variables, $c_{t}, i_{t}, g_{t}, e_{t}, m_{t}$ are the percentage changes in real; consumption, investment, government spending, exports and imports. The coefficients 


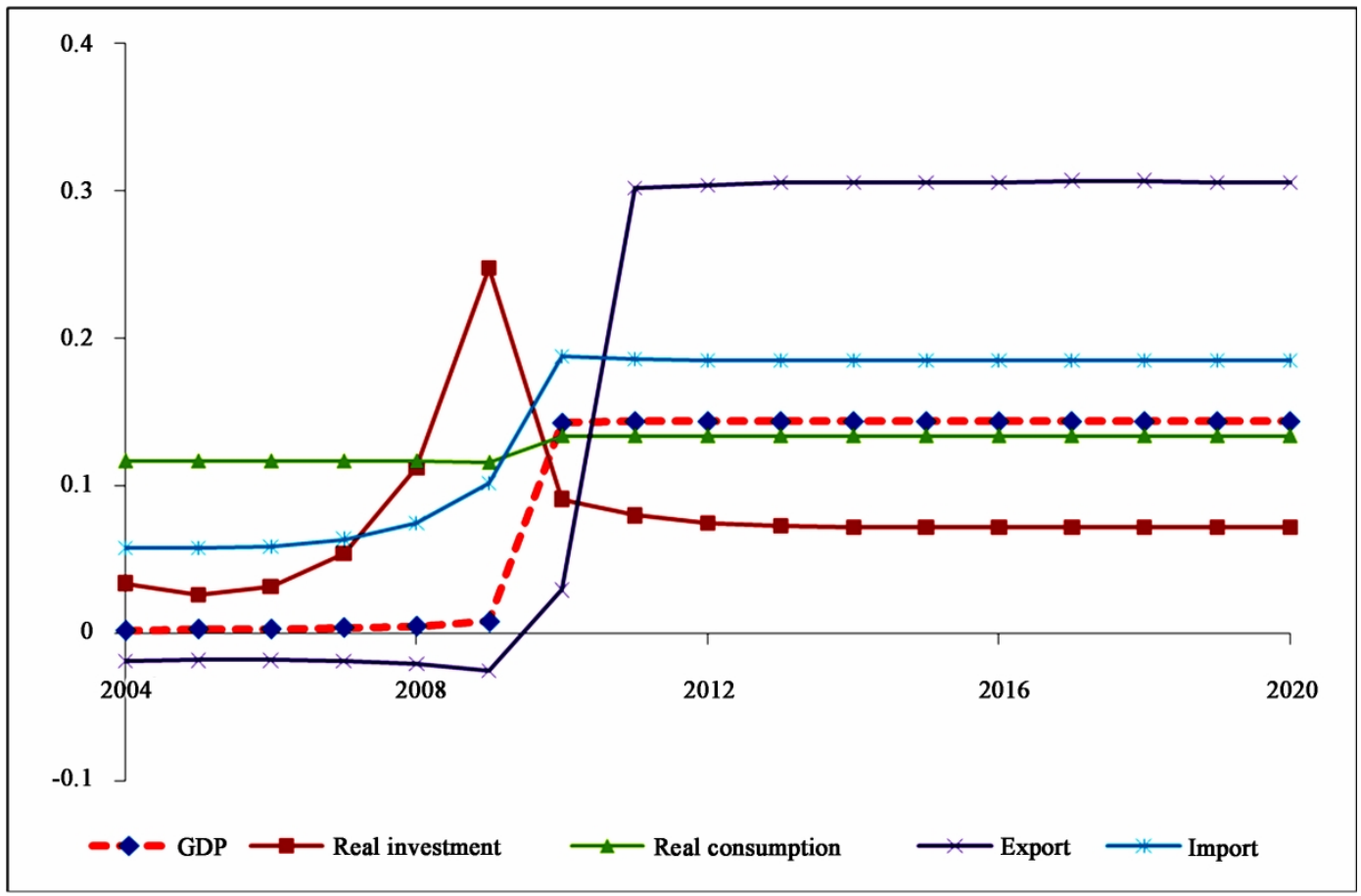

Figure 3. Deviation of macro indicators from baseline (\%, Turkey).

are shares in GDP of consumption, investment, government spending, exports and imports.

Evaluating Equation (2) using values of shares and the simulation results for year of 2020 we obtain;

$$
\begin{aligned}
\operatorname{gdp}_{16}= & 0.66 *(0.13)+0.2 *(0.07)+0.14 *(0.0) \\
& +0.34 *(0.31)-0.34 *(0.19) \\
= & 0.144
\end{aligned}
$$

we can deduce from the evaluation of Equation (2) that about 0.04 percentage $\{0.34 *(0.31)-0.34 *(0.19)\}$ of the 0.14 percent increase in real GDP in 2020 is not available for domestic absorption ( 0.1 percent). Since government expenditure is assumed to remain at its control scenario level that is constant, the deterioration in the terms of trade is absorbed mostly by the Turkish households $\{0.66 * 0.13=0.09$ percent $\}$.

We can reports the macroeconomic costs of implementing the hydro power generation scenario in terms of the percentage change in per capita utility of the representative household and the associated terms-of-trade changes. While the terms of trade deteriorate, welfare of Turkish household (measured in terms of utility of the representative household) increases due to the increased in real consumption.

As can be seen in Figure 4, imposing doubling hydro power generation considerably reduces crude oil production. But, Turkey has no big oil and natural gas reserves. The most promising and significant domestic energy re- sources in Turkey are coal (mainly in the form of lignite), hydro and geothermal. The share of domestic energy resources in terms of world reserves is coal, $0.6 \%$; geothermal energy, $0.8 \%$; and hydroelectric energy, $1 \%$. Proven recoverable oil reserves in Turkey are 38.7 million tons by the end of 2007. In 2007, total oil consumption was 27.69 million tons, of which 25.56 million tons were imported and 2.13 million tons produced domesticcally. Turkey's oil production in 2007 met only $8.0 \%$ of demand and the rest (92\%) was imported, mainly from Russia, Iran, Saudi Arabia, Libya, Iraq, Syria and Algeria. Therefore expanding hydro power generation contributes the lessening the dependency to the imported oil.

The bigger winner from expanding hydro power is energy intensive industries which records 0.36 percent increase in output. The performance of energy intensive industries is dependent on competitiveness of its highly capital intensive commodities and gets additional cost advantage from the fall in the price of electricity.

Simulation results show that expanding hydro power plants have a negative effect on agriculture $(0.04 \%)$. Electricity are also intermediate inputs used by other industries, causing considerable indirect real output rise in the fossil fired electricity $(0.15 \%)$, oil product industries $(0.06 \%)$. Other industries getting particularly affected are gas $(0.3 \%)$ and coal $(0.18 \%)$ and other industries and services $(0.03 \%)$. 


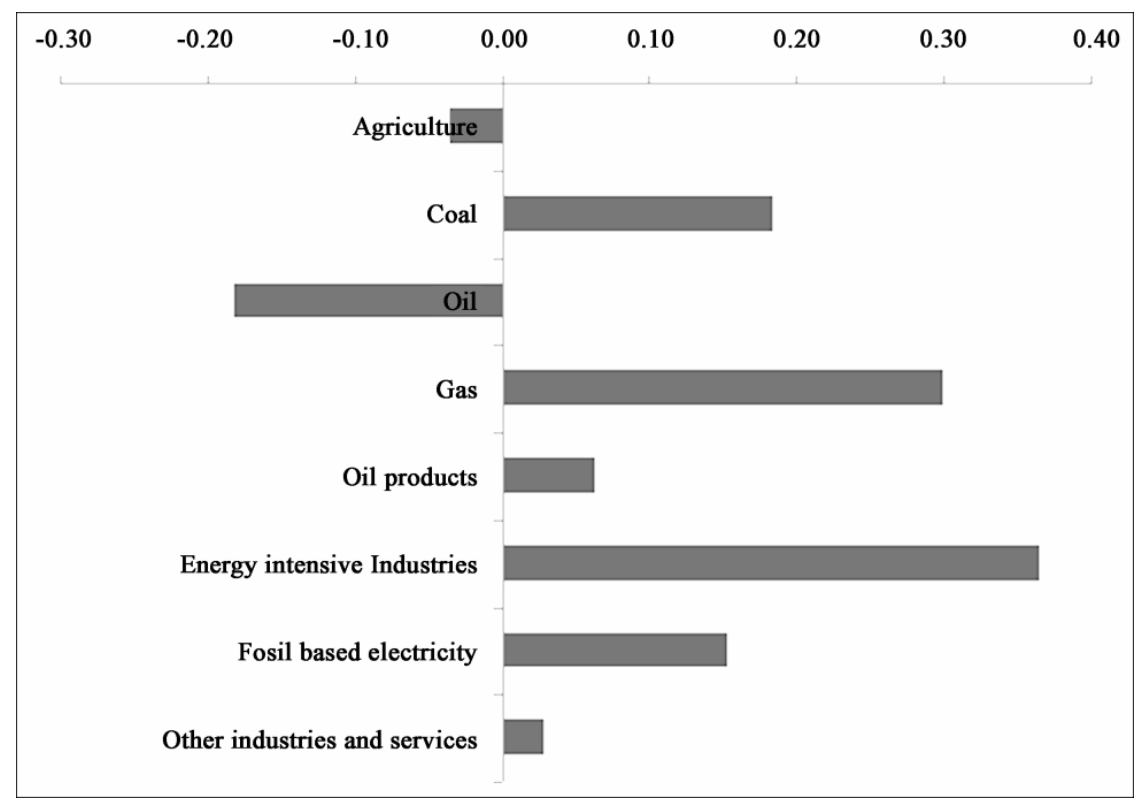

Figure 4. Percent deviation of sectoral output from baseline $(\%, 2020)$.

It should be noted that these are long run effects, since substitution normally occurs in the long run, hence resulting in changes in energy structure. In the end, resources will shift from oil extraction industries to hydro power generation and energy intensive industries.

\subsection{Impact of Expanding Hydro Power Generation on Carbon Emissions}

Expanding of hydro power shock has two interrelated impacts: GDP growth rate impact and energy impact that induce a change in carbon emission level. This section seeks to explore whether the possible power generation shock of the next decade will have any significant effect on carbon emission growth rate in the Turkish economy.

The impact of expanding hydro power on the $\mathrm{CO}_{2}$ emissions is positive but it is not so significant. The carbon emissions is on average $0.012 \%$ lower than the base case over the ten-year simulation period while expanding hydro power generation are assumed to be doubled.

As is known, carbon emissions are closely related to energy consumption. Therefore, $\mathrm{CO}_{2}$ emissions are associated with all emitting activities, including current production, capital formation, and household and govern- ment consumption [17].

The growth rate of carbon emission is defined as the weighted average of a firm's usage and private and government consumption. Commodities emit carbon into the atmosphere when they are burned. We calculate the rate of carbon emission for each region and fossil fuel commodities, gco2(i), as the sum of the carbon emissions of all sources (domestic and imported) and all users (see Equation (3));

Where $\mathrm{i}=\{$ coal, oil, oil products and gas $\}$ and $\mathrm{j}=\{$ all tradable and capital goods $\}$, the coefficients $\mathrm{CO}_{2} \mathrm{DF}$ is the emissions from firms' demand for domestic product, $\mathrm{CO}_{2} \mathrm{IF}$ is the emissions from firms' demand for imports, $\mathrm{CO}_{2} \mathrm{DP}$ is the emissions from the private consumption of domestic product, and so on. The corresponding variables, gco2fd is emissions from firms' demand for domestic product, gco $2 \mathrm{fm}$ is emissions from firms' demand for imports, gco2pd is emissions from the private consumption of domestic product, and so on. We assume that emissions are proportional to demand: for instance, emissions from firms' demand for domestic product can be written as follows:

$$
\operatorname{gco} 2 f d(i, j)=q f d(i, j) .
$$

$$
g \operatorname{co} 2(\mathrm{i}, \mathrm{t})=\frac{1}{\mathrm{CO}_{2}(\mathrm{i}, \mathrm{t})}\left[\begin{array}{l}
\sum_{\mathrm{j}}\left\{\mathrm{CO}_{2} \mathrm{IF}(\mathrm{i}, \mathrm{j}, \mathrm{t}) \operatorname{gco} 2 \mathrm{fm}(\mathrm{i}, \mathrm{j}, \mathrm{t})+\mathrm{CO}_{2} \mathrm{DF}(\mathrm{i}, \mathrm{j}, \mathrm{t}) \operatorname{gco} 2(\mathrm{i}, \mathrm{j}, \mathrm{t})\right\} \\
+\left[\mathrm{CO}_{2} \mathrm{IG}(\mathrm{i}, \mathrm{t}) \operatorname{gco} 2 \mathrm{gm}(\mathrm{i}, \mathrm{t})+\mathrm{CO}_{2} \mathrm{DG}(\mathrm{i}, \mathrm{t}) \operatorname{gco} 2 \mathrm{gd}(\mathrm{i}, \mathrm{t})\right] \\
+\left[\mathrm{CO}_{2} \mathrm{IP}(\mathrm{i}, \mathrm{t}) \operatorname{gco} 2 \mathrm{pm}(\mathrm{i}, \mathrm{t})+\mathrm{CO}_{2} \mathrm{DP}(\mathrm{i}, \mathrm{t}) \operatorname{gco} 2 \mathrm{pd}(\mathrm{i}, \mathrm{t})\right]
\end{array}\right]
$$


Others follow the same pattern. Similarly, we calculate the rate of the economy-wide $\mathrm{CO}_{2}$ emissions for each region, gco2t, as the sum of emissions from the commodities subject to the carbon tax.

$$
\mathrm{gco} 2(\mathrm{t})=\frac{1}{\mathrm{CO}_{2} \mathrm{~T}(\mathrm{t})} \sum_{\mathrm{i}}^{\mathrm{t}} \mathrm{CO}_{2}(\mathrm{i}, \mathrm{t}) \mathrm{gco} 2(\mathrm{i}, \mathrm{t})
$$

where $\mathrm{i}=$ coal, gas, oil products and $\mathrm{t}=1, \mathrm{~L}, \mathrm{~T}$

By using Table 3 and simulation results we can evaluate growth of carbon emission in line with Equation (4) for year of 2020. Table 3 shows the amount of carbon emission released by fuels and percentage changes due to the expanding hydro power generation.

As shown in Figure 3 doubling hydro power generation supply leads to a fall in output of the crude oil pro- duction derived from fossil fuels, thereby contributing to environmental protection through the reduction of carbon dioxide emissions associated with the fossil fuels. The carbon dioxide emissions by the Turkish economy decreases by about 0.012 percent per annum as shown in Figure 5.

In general, the results suggest that the long run effects of expanding hydro power generation in Turkish economy with respect to $\mathrm{CO}_{2}$ emissions and GDP growth move in the reverse direction due to the renewable energy usage instead of fossil fuels emitting carbon into atmosphere. Cumulative output gains over the ten-year projection period resulting from doubled hydro power generation can be as large as 1.5 percent, while cumulitive $\mathrm{CO}_{2}$ emissions loss can be nearly 0.1 percent deviation from baseline.

Table 3. Total carbon emission and its percentage change by fuel type.

\begin{tabular}{ccccc}
\hline Fuel type & $\begin{array}{c}\text { Emission } \\
\text { (Million Ton) }\end{array}$ & $\begin{array}{c}\text { Share of } \mathrm{CO}_{2} \\
\text { Emission }\end{array}$ & $\begin{array}{c}\text { Growth of } \mathrm{CO}_{2} \text { Emission } \\
\text { (Average of 2010-2020) }\end{array}$ & $\begin{array}{c}\text { Percentage change of } \\
\mathrm{CO}_{2} \text { Emission }\end{array}$ \\
\hline Coal & 91 & 0.38 & 0.046 & 0.017 \\
Gas & 42 & 0.17 & 0.065 & 0.011 \\
Oil Products & 109 & 0.45 & -0.089 & -0.040 \\
Total & 242 & 1.00 & & -0.012 \\
\hline
\end{tabular}

Source: GTAP database and own calculations.

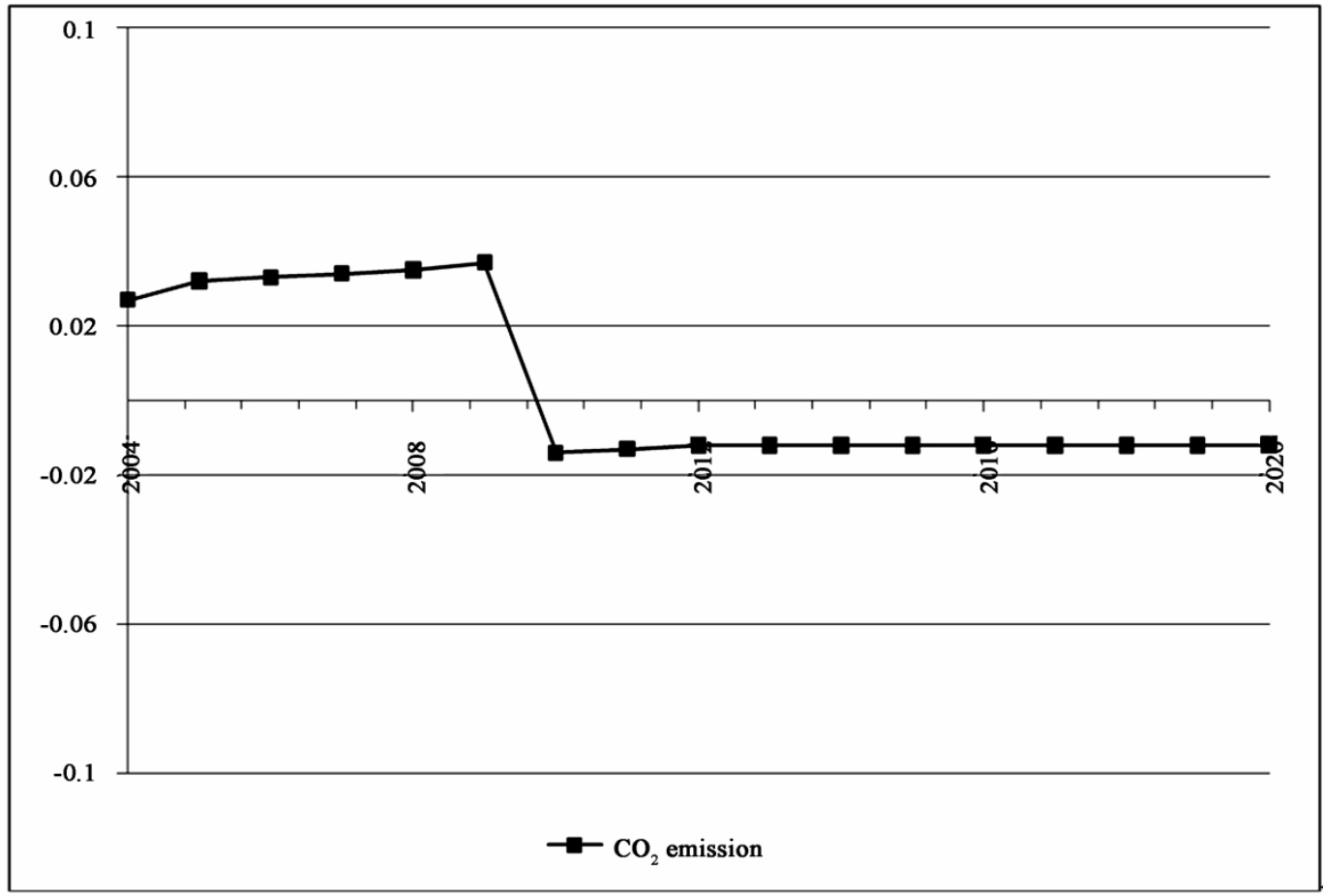

Figure 5. Percent deviation of $\mathrm{CO}_{2}$ emissions from baseline (\%, Turkey). 
The model presented in this article shares many of features incorporated in the models in the intertemporal CGE literature. In order to place TurGEM-D in this literature we outline key features of four models chosen for comparison in table A1 in Appendix. The four models are described by Mercenier and Sampio de Souza [18], Bovering and Goulder [19], Jorgensen and Wilcoxen [20], and McKibbin and Wilcoxen [21]. These models are chosen due to the fact that they represent the latest developments in the class of models to which TurGEM-D model belongs.

\section{Conclusions}

One of the most important conclusions of this study for Turkey as a developing country - as implied by the results of the simulation - is that increasing renewable energy source that is hydro power decrease carbon emissions without reducing economic growth dramatically. The net effects of this scenario would reduce even further the cost of adopting environment friendly energy policies.

While evaluating the results of energy and environmental policies, one should keep in mind that this model measures only deviation from the baseline as to the costs and benefits of these policies. Further potential advantages or disadvantages of hydropower in the context of power generation have not been captured by the model.

As to the policy recommendation for policy makers who have to consider carbon abatement policy without giving up economic development as an ultimate target, we can say the following. Given the fact that some sort of a carbon tax reform is a must in the context of adjustment to the EU energy policies, one option is that carbon tax revenues can be used to finance the adoption of technological change in the form of shifting more towards renewable energy sources.

As another option, they could be used to minimize the burden sharing of energy tax in favor of the producers. Due to the long term positive implications in creating a less carbon-emitting, more energy efficient economy, we suggest that energy tax revenues should be used to finance shifting towards renewable energy-based technology and environment-friendly production structure. Because this is the best policy option in achieving cleaner environment without harming the capital stock, investment possibilities and indirect tax revenues. Utilization of renewable energy sources at a higher degree would further contribute to reducing dependency of Turkey to imported energy sources, hence reinforcing energy supply security.

The introduction of the energy-environmental dimen- sion in TurGEM-D is only one step towards the elaboration of a ORANI framework that is suitable to analyze GHG issues. It is hoped that the current version of TurGEM-D could be further extended in order to analyze some other renewable energy issues, such as new constructing or expanding capacity in nuclear power in electricity generation and using bio-fuels as a fuel in transport sector.

\section{REFERENCES}

[1] B. Dursun and C. Gokcol, "The Role of Hydroelectric Power and Contribution of Small Hydropower Plants for Sustainable Development in Turkey," Renewable Energy, doi:10.1016/j.renene.2010.10.001.

[2] DSI, State Hydraulic Works, "Statistics on Hydropower," Ankara, Turkey. http://www.dsi.gov.tr

[3] M. Ozturk, N. C. Bezir and N. Ozek, "Hydropower- Water and Renewable Energy in Turkey: Sources and Policy," Renewable and Sustainable Energy Reviews, Vol. 13, No. 3, 2009, pp. 605-615.

[4] H. Balat, "A Renewable Perspective for Sustainable Energy Development in Turkey: The Case of Small Hydropower Plants," Renewable and Sustainable Energy Reviews, Vol. 11, No. 9, 2007, pp. 2152-2165.

[5] TEIAS, Directorate-General of Turkish Electricity Transmission. http://www.teias.gov.tr

[6] S. Kucukali and K. Baris, "Assessment of Small Hydropower (SHP) Development in Turkey: Laws, Regulations and EU Policy Perspective," Energy Policy, Vol. 37, No. 10, 2009, pp. 3872-3879.

[7] M. Malakellis, "Integrated Macro-Micro-Modeling under Rational Expectations with an Application to Tariff Reform in Australia," Physica-Verlag, 2000.

[8] P. B. Dixon, B. R. Parmenter, J. Sutton and D. P. Vincent, "ORANI: A Multisectoral Model of the Australian Economy,"Amsterdam, North-Holland, 1982.

[9] TURKSAT, "The Supply-Use and Input-Output Tables," Ankara, 2008. http://www.tuik.gov.tr

[10] World Energy Council, "Energy Statistics," Turkish National Committee, Istanbul, 2004.

[11] A. M. Borges and L. H. Goulder, "Decomposing the Impact of Higher Energy Prices on Long Term Growth," In: H. E. Scarf and J. B. Shoven, Eds., Applied General Equilibrium Analysis, Cambridge University Press, Cambridge, 1984.

[12] W. J. Keller, “Tax Incidence, A General Equilibrium Approach," North Holland, 1980.

[13] J. Burniaux and T. Truong, "GTAP-E: An Energy-Environmental Version of the GTAP Model," GTAP Technical Paper No. 16, Center for Global Trade Analysis, Purdue University, West Lafayette, 2002.

[14] B. V. Dimaranan and R. A. McDougall, "Global Trade, Assistance, and Production: The GTAP 6 Data Base, Center for Global Trade Analysis," Purdue University, 
2005.

[15] W. J. Harrison and K. R. Pearson, "An Introduction to GEMPACK, Document GPD-1," Centre of Policy Studies, Monash University, Clayton, Melbourne, 2000.

[16] W. J. Harrison and K. R Pearson, "Computing Solutions for Large General Equilibrium Models Using GEMPACK," Computational Economics, Vol. 9, No. 2, 1996, pp. 83-127.

[17] L. Aydin and M. Acar, "Economic and Environmental Implications of Turkish Accession to the European Union: A CGE Analysis," Energy Policy, Vol. 38, No. 11, November 2010, pp. 7031-7040.

[18] J. Mercenier and M. Sampaio de Souza, "Structural Adjustment and Growth in a Highly Indebted Market Economy: Brazil," In: J. Mercenier and T. N. Srinivasan, Eds.,
Applied General Equilibrium and Economic Development, University of Michigan Press, Ann arbor, 1994, pp. 281310.

[19] A. L. Bovenberg and L. H. Goulder, "Introducing and Open Economy Features in Applied General Equilibrium Models," In: H. Don van de Klundert and J. Sinderen, Eds., Applied General Equilibrium Analysis, Kluwer Academic Publishers, Dodrectht, 1991, pp. 47-64.

[20] D. W. Jorgensen and P. J. Wolcoxen, "Intertemporal General Equilibrium Modeling of U.S. Environmental Regulation," Journal of Policy Modelling, Vol. 12, No. 4, 1990, pp. 715-744.

[21] W. J. McKibbin and P. J. Wilcoxen, "The Theoretical and Empirical Structure of the G-Cubed Model," Economic Modelling, Vol. 16, No. 1, January 1999, pp. 123-148.

\section{Appendix}

Table A1. Key features of models.

\begin{tabular}{|c|c|c|c|c|c|c|}
\hline & TurGEM-D & ORANI-INT & M-S & B-G & $\mathrm{J}-\mathrm{W}$ & M-W \\
\hline Single country with open economy features & $\sqrt{ }$ & $\sqrt{ }$ & $\sqrt{ }$ & & $\sqrt{ }$ & \\
\hline Sector produces its own capital using sector -specific technology & $\sqrt{ }$ & $\sqrt{ }$ & $\sqrt{ }$ & & & \\
\hline Energy substitution in its structure & $\sqrt{ }$ & & & & $\sqrt{ }$ & \\
\hline Investment decision are driven by forwards-looking rates of return & $\sqrt{ }$ & $\sqrt{ }$ & & & $\sqrt{ }$ & \\
\hline $\begin{array}{l}\text { Time-to-build investment specification that does not incorporate convex } \\
\text { adjustment costs }\end{array}$ & $\sqrt{ }$ & $\sqrt{ }$ & & & $\sqrt{ }$ & \\
\hline Infinitely lived representative household & $\sqrt{ }$ & $\sqrt{ }$ & $\sqrt{ }$ & $\sqrt{ }$ & $\sqrt{ }$ & $\sqrt{ }$ \\
\hline $\begin{array}{l}\text { Labor supply decision are not determined by the solution of utility } \\
\text { maximization problem }\end{array}$ & $\sqrt{ }$ & $\sqrt{ }$ & $\sqrt{ }$ & $\sqrt{ }$ & & $\sqrt{ }$ \\
\hline Government decision is endogenous & $\sqrt{ }$ & $\sqrt{ }$ & $\sqrt{ }$ & & & $\sqrt{ }$ \\
\hline Budget deficit is determined residually. & $\sqrt{ }$ & $\sqrt{ }$ & & & & \\
\hline
\end{tabular}

Sources: Malakallis, 2000

Notes: M-S denotes Merceiner and Sampaio de Souze, B-G denotes Bovenberg and Goulder, J-W denotes Jorgensen and Wilcoxen, M-W denotes McKibbin and Wilcoxen model. 